\title{
Risk factors associated with development of senile cataract
}

\author{
Pragati Garg $\odot$, Ritika Mullick, Bharti Nigam, Priyanka Raj $\odot$ \\ Department of Ophthalmology, Era's Lucknow Medial College and Hospital, Lucknow, India
}

\begin{abstract}
BACKGROUND: Cataract is the most common cause of reversible blindness worldwide, which has been associated with various causative risk factors. Hence, we aim to study the factors that might play a role in cataractogenesis. MATERIAL AND METHODS: A total of 240 eyes of 240 subjects were included for the study, which consisted of 120 cases with age-related cataract and 120 age-matched controls, and in them various factors like blood pressure, body mass index (BMI), smoking, sun exposure, and serum cholesterol were studied.

RESULTS: A statistically significant difference between the two groups was found with respect to smoking profile $(\mathrm{p}=0.007)$, sun exposure $(\mathrm{p}=0.001)$, and serum cholesterol $(\mathrm{p}<0.001)$. Subjects who were smokers, had a longer exposure to sun, and had higher serum cholesterol level were found to be positively associated with development of cataract. No significant association between BMI $(\mathrm{p}=0.384)$ and blood pressure $(\mathrm{p}>0.05)$ was observed.

CONCLUSION: Higher cholesterol levels, increased sun exposure, and smoking habit play a role in the development of senile cataract, and these are modifiable risk factors. Hence, control of these might help in delaying formation and progression of cataract.
\end{abstract}

KEY WORDS: cataract; serum cholesterol; blood pressure; risk factor; smoking

Ophthalmol J 2020; Vol. 5, 17-24

\section{INTRODUCTION}

Cataract is the most common cause of reversible blindness worldwide. According to the World Health Organisation (WHO), around 253 million people in the world are visually impaired, of whom $90 \%$ of the global burden of visual impairment is concentrated in developing countries [1]. Visual impairment caused by cataract leads to not only economic loss, but also impaired quality of life. Cataract is responsible for $50-80 \%$ of bilateral blindness in India [2-4].

Owing to its large impact and public health considerations, cataract has always been a target of continuous epidemiologic research. Insights into causative factors amenable to intervention, genet- ic factors that predispose to disease, and avenues for novel treatment serve to reduce the disease burden [5].

Extensive research has established smoking, diabetes, and ultraviolet (UV) light exposure as the causative risk factors for age-related cataract, while recent studies have identified other potential risk factors like corticosteroid, exogenous oestrogen [6, $7]$, nutrition [8,9], dietary fat and serum lipid [10, $11]$, and genetics $[12,13]$, which might play a role in the development and progression of cataract.

The focus of identification of newer risk factors of cataract is basically driven by the underlying pathogenesis and pathophysiology behind the cataract. Cataractogenesis, is a multifactorial disease 
process that may be initiated or promoted by oxidative damage. Conversely, serum lipids have been shown to have a direct relationship with oxidative stress, and so they seem to play a causative role in the development and progression of cataract. Hence, this study was carried out to analyse the factors that potentially play a role in cataractogenesis.

\section{MATERIAL AND METHODS}

This is a hospital-based case control study, carried out in the Department of Ophthalmology of a tertiary care centre in Lucknow, North India. Over a period of 18 months we recruited 240 subjects for the purpose of this study, which included 120 individuals aged 50 years or above with age-related cataract as cases, and 120 age-matched non-cataractous controls, after obtaining informed and written consent according to the Declaration of Helsinki.

We excluded subjects with corneal opacities that obscured the grading of the cataract, patients with a history of smoking $>10$ pack years, alcohol consumption $20-140 \mathrm{~g} / \mathrm{day}$, diabetes or hypertension, and patients with secondary cataract. Controls were demographically matched with the cases without cataract and followed the exclusion criteria. The study was approved by Institutional Ethics Committee.

For the purpose of the study, detailed history regarding signs and symptoms of cataract, family history of cataract, history of any medicine intake and systemic disease that might influence cataract, any history of intraocular surgeries, and socioeconomic status was obtained. The patients were then subjected to systemic examination for height, weight, body mass index (BMI), blood pressure, and ocular examination for best corrected visual acuity by Snellen's chart, and torch light and slit lamp examination for grading of cataract, which was done according to the Lens Opacities Classification System III (LOCS III) into: nuclear cataract, cortical cataract, and posterior subcapsular cataract. Evaluation of serum cholesterol was done by taking a $5 \mathrm{~mL}$ blood sample from each participant in an EDTA vial and sending it to the Department of Biochemistry.

The statistical analysis was done using Statistical Package for Social Sciences (SPSS) version 21.0. P values, indicating the level of significance, were defined as significant $(\mathrm{p}<0.05)$, highly significant $(\mathrm{p}<0.01)$, and very highly significant $(\mathrm{p}<0.001)$.

\section{RESULTS}

The present study was carried out to assess the environmental risk factors and cholesterol levels in the serum of patients with cataract, and to understand their significance. For this purpose, a case-control study was planned in which 120 cases with senile cataract aged $\geq 50$ years and 120 demographically matched healthy controls were enrolled and distributed into Group I and Group II, respectively.

Ages of patients in Group I ranged from 50 to 85 years whereas those of controls ranged from 50 to 78 years. The majority of Group I (62.5\%) as well as Group II (65.8\%) subjects were aged 50-60 years. The mean age of cases was $60.98 \pm 7.93$ years and that of controls was $59.22 \pm 7.15$ years. Statistically, there was no significant difference between the two groups with respect to age $(p=0.071)$. In Group I the majority of patients were females $(52.5 \%)$ whereas in Group II the majority were males (54.2\%), and the male-to-female ratios in the two groups were 0.9 and 1.18 , respectively. The difference between two groups was not significant statistically $(\mathrm{p}=0.602)($ Tab. 1).

In Group I, a total of 63 (52.5\%) had involvement of right eye whereas the remaining 57 (47.5\%) had involvement of the left eye. The majority had nuclear sclerotic cataract, among which the most common was Grade 3 cataract (23.3\%) followed by those having grade $4(22.5 \%)$, grade $1(11.7 \%)$, and grade $2(10 \%)$ cataract, respectively. Posterior subcapsular cataract was present in $20.0 \%$ of the subjects, and cortical cataract was found in $12.5 \%$ (Fig. 1).

in Group I the mean systolic and diastolic blood pressure values were $123.82 \pm 12.38$ and $78.17 \pm 8.37 \mathrm{mmHg}$, respectively, whereas in Group II these values were $124.20 \pm 11.64$ and $77.52 \pm 8.99 \mathrm{mmHg}$, respectively. On evaluating the data statistically, the difference between two groups was not found to be significant $(\mathrm{p}>0.05)$ (Tab. 2).

In Group I the BMI ranged from 17.10 to 32.40 $\mathrm{kg} / \mathrm{m}^{2}$ whereas in Group II the BMI ranged from 18.1 to $31.7 \mathrm{~kg} / \mathrm{m}^{2}$. In Group I the majority (63.3\%) had BMI within the range $18.5-24.9 \mathrm{~kg} / \mathrm{m}^{2}$ followed by $25.0-29.9 \mathrm{~kg} / \mathrm{m}^{2}(26.7 \%),<18.5 \mathrm{~kg} / \mathrm{m}^{2}$ $(5.8 \%)$, and $>30 \mathrm{~kg} / \mathrm{m}^{2}(4.2 \%)$. In Group II also, the majority (71.7\%) had BMI within the range $18.5-24.9 \mathrm{~kg} / \mathrm{m}^{2}$ followed by $25.0-29.9 \mathrm{~kg} / \mathrm{m}^{2}(22.5 \%),<18.5 \mathrm{~kg} / \mathrm{m}^{2}(3.3 \%)$, and $>30 \mathrm{~kg} / \mathrm{m}^{2}(2.5 \%)$. The mean BMI of Group I 


\begin{tabular}{|c|c|c|c|c|c|}
\hline & \multicolumn{2}{|c|}{$\begin{array}{c}\text { Group I } \\
\text { Cases }(n=120)\end{array}$} & \multicolumn{2}{|c|}{$\begin{array}{c}\text { Group II } \\
\text { Controls }(n=120)\end{array}$} & \multirow[t]{2}{*}{ Statistics } \\
\hline & No. & $\%$ & No. & $\%$ & \\
\hline \multicolumn{6}{|l|}{ Age [years] } \\
\hline $50-60$ & 75 & 62.5 & 79 & 65.8 & \multirow{4}{*}{$\begin{array}{l}t=1.812 \\
p=0.071\end{array}$} \\
\hline $61-70$ & 32 & 26.7 & 31 & 25.8 & \\
\hline$>70$ & 13 & 10.8 & 10 & 8.3 & \\
\hline $\begin{array}{l}\text { Mean age [years] } \\
\pm \mathrm{SD} \text { (range) }\end{array}$ & \multicolumn{2}{|c|}{$\begin{array}{c}60.98 \pm 7.93 \\
(50-85)\end{array}$} & \multicolumn{2}{|c|}{$\begin{array}{c}59.22 \pm 7.15 \\
(50-78)\end{array}$} & \\
\hline \multicolumn{5}{|l|}{ Gender } & $\chi^{2}=1.067$ \\
\hline$M: F$ & \multicolumn{2}{|c|}{0.9} & \multicolumn{2}{|l|}{1.18} & $p=0.302$ \\
\hline
\end{tabular}

SD - standard deviation

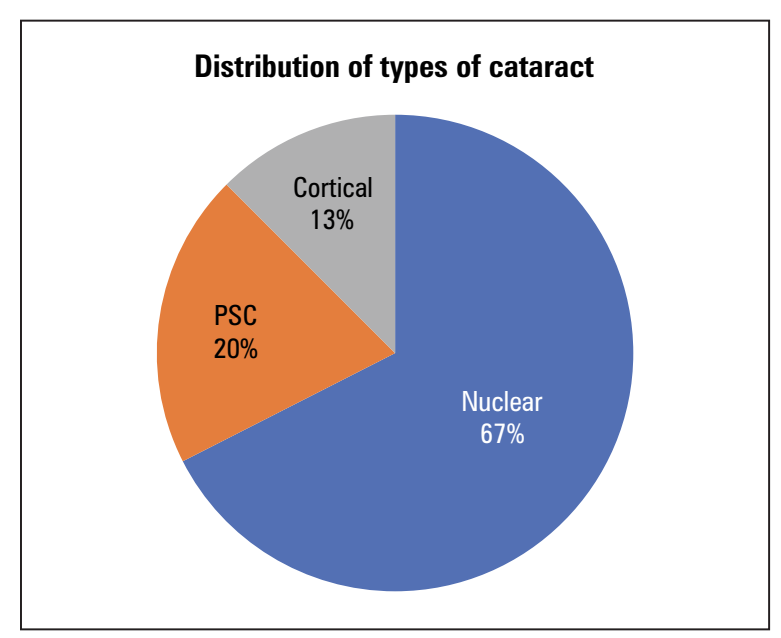

FIGURE 1. Type of cataract; PSC — posterior subcapsular cataract

patients was $23.39 \pm 3.09 \mathrm{~kg} / \mathrm{m}^{2}$ as compared to $23.04 \pm 3.12 \mathrm{~kg} / \mathrm{m}^{2}$ for Group II subjects. Statistically, there was no significant difference between the two groups with respect to BMI ( $p=0.384)$ (Tab. 3).

In Group I, a total of $57(47.5 \%)$ were non-smokers, 17 (14.2\%) were smokers of up to five packs/year, and 46 (38.3\%) were smokers of 5-10 packs/year. Compared to this, the majority of Group II (59.2\%) subjects were non-smokers,
$25(20.8 \%)$ were smokers of up to five packs/year, and $24(20 \%)$ were smokers of 5-10 packs/year. Statistically, the difference between two groups was found to be significant $(p=0.007)$. The majority of Group I patients had duration of sun exposure $>6 \mathrm{hrs} /$ week $(65.8 \%)$ whereas the majority of Group II subjects had duration of sun exposure $<6 \mathrm{hrs} /$ week $(55.8 \%)$. On comparing the data statistically, the difference between the two groups was found to be significant $(\mathrm{p}=0.001)$ (Tab. 3).

Compared to Group II, Group I subjects had significantly higher mean cholesterol levels $(\mathrm{p}<0.001)$. Mean serum cholesterol levels were minimum grade $3(170.11 \pm 26.12 \mathrm{mg} / \mathrm{dL})$ and maximum grade $2(192.92 \pm 33.71 \mathrm{mg} / \mathrm{dL})$; however, the difference among different grades was not statistically significant $(\mathrm{p}=0.093)($ Tab. 4) .

Total cholesterol had area under curve $($ AUC $)=0.603$. The sensitivity and specificity ranged from $61.7 \%$ and $52.5 \%$, respectively (Fig. 2).

On evaluating the role of different variables found to be significantly associated with cataract in univariate assessment through a multivariate predictive model for cataract, neither smoking, sun exposure, nor cholesterol were shown to have any significant association with cataract (Tab. 5).

\begin{tabular}{|l|c|c|c|c|c|c|}
\hline \multirow{2}{*}{ Table 2. Systolic and diastolic blood pressure between the two groups } \\
\hline \multirow{2}{*}{ Parameter } & \multicolumn{2}{|c|}{$\begin{array}{c}\text { Group I } \\
\text { Cases (n= 120) }\end{array}$} & \multicolumn{2}{c|}{$\begin{array}{c}\text { Group II } \\
\text { Controls (n= 120) }\end{array}$} & \multicolumn{2}{c|}{ Statistical significance } \\
\cline { 2 - 7 } & Mean & SD & Mean & SD & t & p \\
\hline SBP $[\mathrm{mmHg}]$ & 123.82 & 12.38 & 124.20 & 11.64 & 0.247 & 0.805 \\
\hline DBP $[\mathrm{mmHg}]$ & 78.17 & 8.37 & 77.52 & 8.99 & 0.580 & 0.563 \\
\hline
\end{tabular}

SBP — systolic blood pressure; DBP — diastolic blood pressure; SD — standard deviation 


\begin{tabular}{|c|c|c|c|c|c|}
\hline \multirow[t]{2}{*}{ Characteristics } & \multicolumn{2}{|c|}{$\begin{array}{c}\text { Group I } \\
\text { Cases }(n=120)\end{array}$} & \multicolumn{2}{|c|}{$\begin{array}{c}\text { Group II } \\
\text { Controls }(n=120)\end{array}$} & \multirow{2}{*}{$\begin{array}{l}\text { Statistical } \\
\text { significance }\end{array}$} \\
\hline & No. & $\%$ & No. & $\%$ & \\
\hline \multicolumn{6}{|l|}{ BMI } \\
\hline$<18.5$ & 7 & 5.8 & 4 & 3.3 & \multirow{4}{*}{$\begin{array}{l}t=0.872 \\
p=0.384\end{array}$} \\
\hline $18.5-24.9$ & 76 & 63.3 & 84 & 71.7 & \\
\hline $25.0-29.9$ & 32 & 26.7 & 27 & 22.5 & \\
\hline$\geq 30$ & 5 & 4.2 & 3 & 2.5 & \\
\hline $\begin{array}{l}\text { Mean BMI }\left[\mathrm{kg} / \mathrm{m}^{2}\right] \pm S D \\
\text { (range) }\end{array}$ & \multicolumn{2}{|c|}{$\begin{array}{c}23.39 \pm 3.09 \\
(17.10-32.40)\end{array}$} & \multicolumn{2}{|c|}{$\begin{array}{c}23.04 \pm 3.12 \\
(18.1-31.7)\end{array}$} & \\
\hline \multicolumn{6}{|l|}{ Sun exposure } \\
\hline$<6$ hrs/week & 41 & 34.2 & 67 & 55.8 & \multirow{2}{*}{$\begin{array}{l}\chi^{2}=11.38 \\
p=0.001\end{array}$} \\
\hline$>6 \mathrm{hrs} /$ week & 79 & 65.8 & 53 & 44.2 & \\
\hline \multicolumn{6}{|l|}{ Smoking habit } \\
\hline No & 57 & 47.5 & 71 & 59.2 & \multirow{3}{*}{$\begin{array}{c}\chi^{2}=9.969(\mathrm{df}=2) \\
p=0.007\end{array}$} \\
\hline Up to 5 packs/year & 17 & 14.2 & 25 & 20.8 & \\
\hline 5-10 packs/year & 46 & 38.3 & 24 & 20.0 & \\
\hline
\end{tabular}

$\mathrm{BMI}$ - body mass index; SD — standard deviation

\begin{tabular}{|c|c|c|c|c|c|c|c|}
\hline \multicolumn{6}{|c|}{$\begin{array}{c}\text { Group I } \\
\text { Cases }(n=120)\end{array}$} & $\begin{array}{c}\text { Group II } \\
\text { Controls }(n=120)\end{array}$ & $\begin{array}{l}\text { Statistical } \\
\text { significance }\end{array}$ \\
\hline \multicolumn{6}{|c|}{$\begin{array}{c}179.72 \pm 28.90 \\
(110-280)\end{array}$} & $\begin{array}{c}153.59 \pm 31.11 \\
(100-220)\end{array}$ & $\begin{array}{l}t=6.625 \\
p<0.001\end{array}$ \\
\hline $\begin{array}{c}\text { PSC } \\
(n=24)\end{array}$ & $\begin{array}{l}\text { Cortical } \\
(n=15)\end{array}$ & \multicolumn{4}{|c|}{$\begin{array}{l}\text { Nuclear } \\
(\mathrm{n}=\mathbf{8 1})\end{array}$} & & \\
\hline \multirow[t]{3}{*}{$179.38 \pm 22.34$} & $170.93 \pm 22.45$ & \multicolumn{4}{|c|}{$181.44 \pm 31.52$} & & $\begin{array}{l}F=0.837 \\
p=0.436\end{array}$ \\
\hline & & $\begin{array}{l}\text { Grade } 1 \\
(n=14)\end{array}$ & $\begin{array}{l}\text { Grade } 2 \\
(n=12)\end{array}$ & $\begin{array}{l}\text { Grade } 3 \\
(\mathrm{n}=28)\end{array}$ & $\begin{array}{l}\text { Grade } 4 \\
(n=27)\end{array}$ & & \\
\hline & & $189.86 \pm 40.92$ & $192.92 \pm 33.71$ & $170.11 \pm 26.12$ & $183.74 \pm 28.06$ & & $\begin{array}{l}F=2.214 \\
p=0.093\end{array}$ \\
\hline
\end{tabular}

PSC — posterior subcapsular cataract

\section{DISCUSSION}

Despite cataract being one of the most common causes of preventable blindness, there is limited understanding regarding the exact aetiology and pathogenesis. Cataract is often referred to as a multi-aetiological process. Laboratory investigations suggest that age-related cataract might result from oxidative stress after sunlight exposure [14]. Animal and observational studies suggest that a diet low in antioxidant micronutrients may increase the risk of lens opacification. Cholesterol levels have also been shown to produce oxidative stress [15]. Incidentally, cholesterol levels and cataract have both been shown to be age related, and hence a temporal relationship cannot be ruled out. Taking into account the oxidative stress-induced pathogenesis of cataract, it may be hypothesised that levels of antioxidant micronutrients might be lower while cholesterol levels might be higher among cataract patients.

In order to test this hypothesis, the present study was planned as a case-control study in which $120 \mathrm{pa}-$ tients of senile cataract (aged $>50$ years) were included as cases and an equal number of age- and sex-matched individuals without cataract were included as controls. Serum total cholesterol levels were included as representative of an oxidative stress-inducing condition. The mean age of patients was $60.98 \pm 7.93$ years, and the majority were females (52.5\%). 


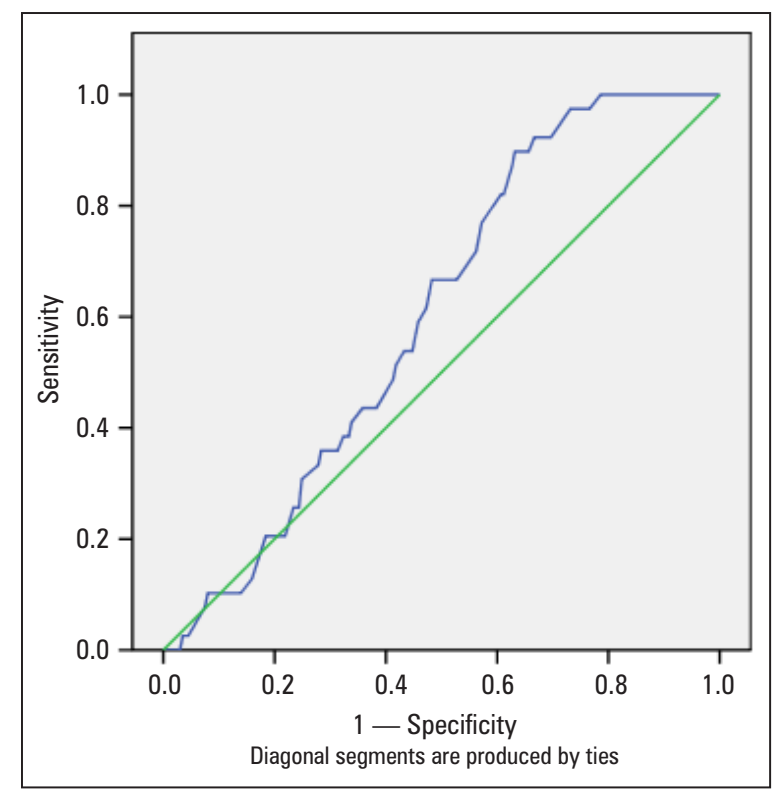

FIGURE 2. Area under curve for cholesterol. ROC — receiver operating characteristic curve

In the present study, the BMI of patients ranged from 17.10 to $32.40 \mathrm{~kg} / \mathrm{m}^{2}$. The mean BMI of patients was $23.39 \pm 3.09 \mathrm{~kg} / \mathrm{m}^{2}$, and the majority of patients were within normal BMI range (63.3\%). Compared to the present study, Nourmohammadi et al. [16] found the mean BMI of patients to be $24.02 \pm 4.10 \mathrm{~kg} / \mathrm{m}^{2}$, while Abbaszadeh et al. [17] reported a mean BMI of cataract patients of $25.04 \pm 3.69 \mathrm{~kg} / \mathrm{m}^{2}$. Compared to this, western studies report relatively high BMI in cataract patients. In the Italian-American Clinical Trial of Nutritional Supplements and Age-related Cataract (CTNS) [26], the majority of patients were overweight $(55 \%)$ and almost one quarter $(23.6 \%)$ were obese. Karppi et al. [18] reported a mean BMI of cataract patients of $27.5 \pm 4.4 \mathrm{~kg} / \mathrm{m}^{2}$ in their study among the elderly Finnish population. These findings in general suggest that while BMI could be a risk factor for cataract in western populations, it does not seem to be very significant in Asian populations. Bearing in mind the probable role of micronutrients in the determination of BMI, there could be differences in micronutrient levels among different populations.

The controls were statistically matched to cases with respect to age, gender, and BMI, thus showing that these factors did not have a confounding effect.

In the present study, the eye with the higher grade of cataract was included among cases. With respect to the side involved, both right (52.5\%) and left $(47.5 \%)$ eyes were involved almost equally. As such, no predisposition of side of eye with cataract has been reported in literature. The present study, showing almost equal distribution of left and right sides, also showed that the side involved is determined by chance rather than by any particular side-related risk. The present study did not include any diabetic or hypertensive patient as per the exclusion criteria of the study. Consecutively, the systolic and diastolic blood pressure values of two cases and controls were matched statistically.

In the present study, the majority of cataract patients were smokers (52.5\%). Among smokers ( $\mathrm{n}=63)$ too, majority smoked 5-10 packs/year (46/63; 73.0\%). In present study we excluded those smoking > 10 pack-years. Smoking is known to be a risk factor for development of age-related cataract [19]. Smoking might also induce oxidative stress $[20,21]$ and affect the level of antioxidant micronutrients and lipids $[22,23]$ under different health conditions. On the other hand, the proportion of smokers and those with smoking habit 5-10 packs/year was significantly lower in controls. These findings suggested that smoking habit was a confounding factor in our study.

In the present study, the majority of cases $(65.8 \%)$ had sunlight exposure $>6 \mathrm{hrs} /$ week as compared to $44.2 \%$ of controls. Thus, the proportion of those having sunlight exposure $>6 \mathrm{hrs} /$ week

\begin{tabular}{|l|c|c|c|c|c|c|c|c|}
\hline Table 5. Multivariate assessment & Wariables & B & SE & Wald & df & Sig. & Exp (B) & \multicolumn{2}{|c|}{$\begin{array}{c}95.0 \% \text { CI } \\
\text { for Exp(B) }\end{array}$} \\
\cline { 5 - 10 } & & & & & & & & \\
Smowing & -.413 & .222 & 3.456 & 1 & .063 & .661 & .428 & 1.023 \\
\hline Sun exposure & -.017 & .404 & .002 & 1 & .967 & .984 & .446 & 2.170 \\
\hline Cholesterol & -.002 & .007 & .064 & 1 & .800 & .998 & .986 & 1.011 \\
\hline Constant & -.945 & 1.317 & .515 & 1 & .473 & 2.573 & & \\
\hline
\end{tabular}

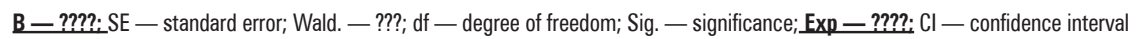


was significantly higher in cases as compared to that in controls. Laboratory investigations have suggested that age-related cataract might result from oxidative stress after sunlight exposure [24, 25]. The findings of the present study also validated this proposition.

Mean serum cholesterol levels were significantly higher in cases as compared to those in controls. In their study, Karppi et al. [18] did not find a significant difference between those having nuclear cataract and those not having cataract for cholesterol level; however, their study was a cross-sectional study among cataract patients in a significantly older age group and having a significantly lower proportion of males as compared to those not having controls. Moreover, in their study, a significant difference between the two groups was also found for alcohol consumption. Owing to these confounding effects, the antioxidant micronutrient and lipid levels in their study might have been affected. In the present study we identified smoking and sunlight exposure as possible reasons for inducing oxidative stress and affecting antioxidant micronutrient levels.

We also found that increased cholesterol levels are associated with cataract risk. A number of previous studies have also endorsed this association in different populations [26-34].

We also investigated cholesterol levels among different types of cataract (posterior capsular, nuclear, and cortical cataract cases) but did not find a significant difference in cholesterol levels among different cataract types. Also, with respect to cholesterol levels, a number of studies supported that all types of cataract are affected by higher cholesterol levels too. However, Al-Talqani et al. [26] found that dyslipidaemia was associated significantly with nuclear and cortical cataract, but it was not associated significantly with posterior subcapsular cataract. Cholesterol representing approximately $40 \%$ of the total lipids of human lens fibres, and intrinsic or extrinsic factors modifying its level and/or repartition may alter optical lens properties. Some cholesterols can be present as crystals, which have been found in plasma membranes isolated from the lens, and which may play functional roles in normal and pathological lens. The formation of these crystals is related to the lipid composition of the lens and seems to depend on the presence of sphingomyelin and dihydrosphingomyelin. The part played by cholesterol in the development of cataract is also supported by observations performed in various pathologies associated with defects in cholesterol metabolism. Thus, patients with Smith-Lemli-Opitz syndrome, mevalonic aciduria, or cerebrotendinous xanthomatosis characterised by mutations in enzymes of cholesterol metabolism (7- dehydrocholesterol reductase, mevanolate kinase, and CYP27A1, resp.) often develop cataract [27]. Moreover, with regards to oxidative damage, because the lipid lens composition is devoid of oxidisable polyunsaturated fatty acids, and because there is a high content of dihydrosphingomyelin that is less prone to oxidation, this particular lipid composition favours cholesterol autoxidation. Thus, because human lens membrane contains the highest cholesterol levels of any known biological membranes, and because human lens is continuously in a strong photoxidative environment, chronic exposure to UV light and ozone can lead to the formation of some cholesterol oxide derivatives (also named oxysterols) [28, 29], which might contribute to disruption of cholesterol repartition and homeostasis in human lens fibres.

Hiller et al. [30] reported a longitudinal data series to find the association between serum lipids and age-related lens opacities. In this multistage analysis fasting hypertriglyceridaemia ( $\geq 250 \mathrm{mg} / \mathrm{dL}$ ) was associated with an increased risk of posterior subcapsular cataract (PSC) in men ( $\mathrm{p}=0.02)$. High-density lipoprotein cholesterol levels $\leq 35 \mathrm{mg} / \mathrm{dL}$ were associated with PSC cataract in men at a borderline level of significance $(p=0.09)$. No associations were noted between serum lipid/lipoprotein variables and risk of cortical or nuclear cataract. These findings suggested that hypertriglyceridaemia, a potentially modifiable factor, is associated with the development of PSC cataract in men.

Heydari et al. [31] evaluated the relationship between cataract development and serum lipids, glucose, and antioxidants in a case-control study. They found that plasma TG $(\mathrm{p}=0.02)$, cholesterol $(\mathrm{p}=0.001)$, and low-density lipoprotein cholesterol $(\mathrm{LDL}-\mathrm{C})(\mathrm{p}=0.04)$ were significantly higher in the cataract group than in the control group.

Park et al. [32] conducted an analysis of data from the Korea National Health and Nutrition Examination Surveys (2008-2010). Reduced high-density lipoprotein cholesterol (HDL-C), elevated fasting glucose, and elevated triglycerides (TG) were also significantly associated with cataract in women [aOR, 95\% CI; 1.27 (1.07-1.50), $1.23(1.01-1.50)$, and $1.26(1.04-1.52)$, respectively]. In the subgroup analysis for cataract subtype, MetS and reduced HDL-C were significantly associated with nuclear cataract in women $[\mathrm{aOR}$, 
95\% CI; $1.25(1.07-1.55)$ and 1.25 (1.03-1.52), respectively]. However, such associations were not found in men.

In a similar study Uppu and Gupta [33] also found a significant difference between the case and control groups for all the lipids including total cholesterol, TG, LDL, and very low-density lipoprotein (VLDL) but not HDL levels $(\mathrm{p}<0.001)$. No significant difference was observed between the two groups for serum fasting glucose levels. The authors were of the view that oxidative stress may play an import role in the senile cataract.

Al-Talqani et al. [26] also found a significant association between the prevalence of dyslipidaemia $(\mathrm{p}<0.05)$ with nuclear and cortical cataract, but it was not significant $(>0.05)$ for posterior subcapsular cataract.

Li et al. [34] in a case control study found that the serum LDL-C, TG, cholesterol, and apolipoprotein A (APOA) levels were significantly higher $(\mathrm{p}<0.05)$ in the cataract group than in the control group. The findings of the study thus showed that lipid levels pose a significant risk of age-related cataract.

In the present study, among different grades of nuclear cataract, we also did not find a significant difference in cholesterol levels, and we did not find any significant association between the grade of nuclear cataract and lipid levels. One of the reasons for this could be the lower number of cases in lower grades (Grade I and II) in our series.

In view of these findings, we attempted to derive cut-off values for total cholesterol levels for discrimination between cataract and non-cataract subjects. We found that total cholesterol levels were least sensitive and specific $(61.7 \%$ sensitivity and $52.5 \%$ specificity) at a cut-off of $>169.5 \mathrm{mg} / \mathrm{dL}$.

In previous studies, despite showing the role of cholesterol levels, no such discriminant role had been analysed. In the present study, despite deriving these cut-off values, we feel that they have limited practical value because it was carried out as a case-control study and included subjects falling within predefined inclusion and exclusion criteria. Bearing in mind the fact that cholesterol levels play roles also in other diseases, the diagnostic/discriminant value of these parameters has limited practical application and more such studies are needed to confirm the usefulness of these cut-off values.

In the present study, on binary logistic regression, taking smoking, sun exposure, and cholesterol levels as independent predictors of cataract, none of them showed a significant association with cataract.

\section{CONCLUSION}

The present study thus endorsed the findings that antioxidant micronutrients and cholesterol levels play a significant role in causation of senile cataract, as proposed by various previous studies. The present study also highlighted that increased sun exposure and smoking habit could play a detrimental role in oxidative stress, which affected the antioxidant levels and lipid levels and thus played a role in the pathogenesis of cataract.

\section{Acknowledgements}

None.

\section{Conflict of interest}

Authors declare that there was no conflict of interest in the publication of this study.

\section{REFERENCES}

1. World Health Organization. Blindness and visual impairment. WHO Fact Sheet dated 11 October, 2017. http://www.who.int/en/news-room/ fact-sheets/detail/blindness-and-visual-impairment (1st May, 2018).

2. Thulasiraj RD, Nirmalan PK, Ramakrishnan $R$, et al. Blindness and vision impairment in a rural south Indian population: the Aravind Comprehensive Eye Survey. Ophthalmology. 2003; 110(8): 1491-1498, doi: 10.1016/S0161-6420(03)00565-7, indexed in Pubmed: 12917162.

3. Thulasiraj RD, Rahamathulla R, Saraswati A, et al. The Sivaganga eye survey: I. Blindness and cataract surgery. Ophthalmic Epidemiol. 2002; 9(5): 299-312, doi: 10.1076/opep.9.5.299.10334, indexed in Pubmed: 12528915.

4. Nirmalan PK, Thulasiraj RD, Maneksha V, et al. A population based eye survey of older adults in Tirunelveli district of south India: blindness, cataract surgery, and visual outcomes. Br J Ophthalmol. 2002; 86(5): 505-512, doi: 10.1136/bjo.86.5.505, indexed in Pubmed: 11973242.

5. West SK, Valmadrid CT, West SK, et al. Epidemiology of risk factors for age-related cataract. Surv Ophthalmol. 1995; 39(4): 323-334, doi: 10.1016/s0039-6257(05)80110-9, indexed in Pubmed: 7725232.

6. Younan $C$, Mitchell $P$, Cumming RG, et al. Hormone replacement therapy, reproductive factors, and the incidence of cataract and cataract surgery: the Blue Mountains Eye Study. Am J Epidemiol. 2002; 155(11): 997-1006, doi: 10.1093/aje/155.11.997, indexed in Pubmed: 12034578.

7. Mukesh BN, Le A, Dimitrov PN, et al. Development of cataract and associated risk factors: the Visual Impairment Project. Arch Ophthalmol. 2006; 124(1): 79-85, doi: 10.1001/archopht.124.1.79, indexed in Pubmed: 16401788.

8. Wu SY, Leske MC. Antioxidants and cataract formation: a summary review. Int Ophthalmol Clin. 2000; 40(4): 71-81, doi: 10.1097/00004397200010000-00006, indexed in Pubmed: 11064858.

9. Leske MC, Chylack LT, Wu SY, et al. The Lens Opacities Case-Control Study. Risk factors for cataract. Arch Ophthalmol. 1991; 109(2): 244-251, doi: 10.1001/archopht.1991.01080020090051, indexed in Pubmed: 1993036.

10. Hiller R, Sperduto RD, Reed GF, et al. Serum lipids and age-related lens opacities: a longitudinal investigation: the Framingham Studies. Ophthalmology. 2003; 110(3): 578-583, doi: 10.1016/S01616420(02)01762-1, indexed in Pubmed: 12623825.

11. Jahn $C E$, Janke $M$, Winowski $H$, et al. Identification of metabolic risk factors for posterior subcapsular cataract. Ophthalmic Res. 
1986; 18(2): 112-116, doi: 10.1159/000265424, indexed in Pubmed: 3737111.

12. Familial aggregation of lens opacities: the Framingham Eye Study and the Framingham Offspring Eye Study. Am J Epidemiol. 1994; 140(6): 555-564, indexed in Pubmed: 8067349.

13. Heiba IM, Elston RC, Klein BE, et al. Evidence for a major gene for cortical cataract. Invest Ophthalmol Vis Sci. 1995; 36(1): 227-235, indexed in Pubmed: 7822150.

14. Young RW. The family of sunlight-related eye diseases. Optom Vis Sci. 1994; 71(2): 125-144, doi: 10.1097/00006324-199402000-00013, indexed in Pubmed: 8152745.

15. Rao V, Kiran R. Evaluation of correlation between oxidative stress and abnormal lipid profile in coronary artery disease. J Cardiovasc Dis Res. 2011; 2(1): 57-60, doi: 10.4103/0975-3583.78598, indexed in Pubmed: 21716754.

16. Nourmohammadi I, Modarress M, Khanaki K, et al. Association of serum alpha-tocopherol, retinol and ascorbic acid with the risk of cataract development. Ann Nutr Metab. 2008; 52(4): 296-298, doi: 10.1159/000148189, indexed in Pubmed: 18663288.

17. Abbaszadeh M, Aidenloo NS, Motarjemizadeh Q, et al. Lack of association between plasma levels of vitamin $C$ and nuclear cataract. Bull Env Pharmacol Life Sci. 2016; 6(1): 1-5.

18. Karppi J, Laukkanen JA, Kurl S. Plasma lutein and zeaxanthin and the risk of age-related nuclear cataract among the elderly Finnish population. Br J Nutr. 2012; 108(1): 148-154, doi: 10.1017/ S0007114511005332, indexed in Pubmed: 22005336.

19. Ye J, Lou LX, He JJ, et al. Smoking and risk of age-related cataract: a meta-analysis. Invest Ophthalmol Vis Sci. 2012; 53(7): 3885-3895, doi: 10.1167/iovs.12-9820, indexed in Pubmed: 22599585.

20. Isik $B$, Ceylan $A$, Isik R. Oxidative stress in smokers and non-smokers. Inhal Toxicol. 2007; 19(9): 767-769, doi: 10.1080/08958370701401418, indexed in Pubmed: 17613085.

21. Donohue JF. Ageing, smoking and oxidative stress. Thorax. 2006; 61(6): 461-462, doi: 10.1136/thx.2005.053058, indexed in Pubmed: 16738041.

22. Gepner AD, Piper ME, Johnson HM, et al. Effects of smoking and smoking cessation on lipids and lipoproteins: outcomes from a randomized clinical trial. Am Heart J. 2011; 161(1): 145-151, doi: 10.1016/j. ahj.2010.09.023, indexed in Pubmed: 21167347.
23. Sinha AK, Misra GC, Patel DK. Effect of cigarette smoking on lipid profile in the young. J Assoc Physicians India. 1995; 43(3): 185-188, indexed in Pubmed: 11256905.

24. Young RW. The family of sunlight-related eye diseases. Optom Vis Sci. 1994; 71(2): 125-144, doi: 10.1097/00006324-199402000-00013, indexed in Pubmed: 8152745.

25. Ayala MN, Michael R, Söderberg PG. Influence of exposure time for UV radiation-induced cataract. Invest Ophthalmol Vis Sci. 2000; 41(11): 3539-3543, indexed in Pubmed: 11006249.

26. Al-Talqani HM, Taher AA, Jabouri BB. Dyslipidemia and cataract in adult Iraqi patients . EC Ophthalmol. 2017; 5(5): 162-171.

27. Cenedella R. Cholesterol and cataracts. Surv Ophthalmol. 1996; 40(4): 320-337, doi: 10.1016/s0039-6257(96)82007-8, indexed in Pubmed: 8658343.

28. Wentworth P, Nieva J, Takeuchi C, et al. Evidence for ozone formation in human atherosclerotic arteries. Science. 2003; 302(5647): 1053-1056, doi: 10.1126/science.1089525, indexed in Pubmed: 14605372.

29. Dreyfus MA, Tolocka MP, Dodds SM, et al. Cholesterol ozonolysis: kinetics, mechanism, and oligomer products. J Phys Chem A. 2005; 109(28): 6242-6248, doi: 10.1021/jp050606f, indexed in Pubmed: 16833964.

30. Hiller R, Sperduto RD, Reed GF, et al. Serum lipids and age-related lens opacities: a longitudinal investigation: the Framingham Studies. Ophthalmology. 2003; 110(3): 578-583, doi: 10.1016/S01616420(02)01762-1, indexed in Pubmed: 12623825.

31. Heydari B, Kazemi T, Zarban A, et al. Correlation of cataract with serum lipids, glucose and antioxidant activities: a case-control study. West Indian Med J. 2012; 61(3): 230-234, doi: 10.7727/wimj.2011.103, indexed in Pubmed: 23155978.

32. Park YH, Shin JAh, Han K, et al. Gender difference in the association of metabolic syndrome and its components with age-related cataract: the Korea National Health and Nutrition Examination Survey 2008-2010. PLoS One. 2014; 9(1): e85068, doi: 10.1371/journal.pone.0085068, indexed in Pubmed: 24416342.

33. Li S, Li D, Zhang Y, et al. Association between serum lipids concentration and patients with age-related cataract in China: a cross-sectional, case-control study. BMJ Open. 2018; 8(4): e021496, doi: 10.1136/ bmjopen-2018-021496, indexed in Pubmed: 29626052. 